\title{
The manifesto of money (the neutrality of money)
}

\section{Eduardo Rivera Vicencio}

Faculty of Economics and Business, Autonomous University of Barcelona, Barcelona, Spain Email: Eduardo.Rivera@uab.es

\begin{abstract}
The vast majority of what has been written about the monetary system and its theories was developed when money was totally or partially backed by some type of merchandise. At present, commodity money no longer exists, only debt money. This paper addresses money from its transition to the current situation, through this 'manifesto of money', for the construction of a new theoretical framework that adapts to the current reality and adopting money as a real medium of exchange. This paper uses the methodology of historical review and of existing power relations in this historical moment in time called the archaeological and genealogical methodology by Foucault. Using this tool, a review of the related economic literature is made and the incongruities of the current monetary system are described. The central axis of this work is the 'neutrality of money' which is used to develop a proposal for a national currency and a proposal for an international exchange currency as the basis for the construction of a new model.
\end{abstract}

Keywords: money neutrality; monetary supply; manifesto; Foucault; debt money; national currency; international currency; monetary system.

Reference to this paper should be made as follows: Rivera Vicencio, E. (2021) 'The manifesto of money (the neutrality of money)', Int. J. Critical Accounting, Vol. 12, No. 3, pp.229-258.

Biographical notes: Eduardo Rivera Vicencio is a Professor of the Department of Business and Economics at the Autonomous University of Barcelona. He is a committee member of the ACCID Management Accounting Commission (Associació Catalana de Comptabilitat i Direcció/Catalan Accounting and Direction Association) and an editorial board member of the International Journal of Critical Accounting (IJCA), African Journal of Accounting, Auditing and Finance (AJAAF) and Journal of Governance and Regulation. He is the President of the South American Research Section of the Critical Accounting Society and Business Consultant.

\section{General background}

The various aspects to be considered in the historical conformation of the quantitative theory of money, such as the construction of the current monetary system, must have as a central axis a critical perspective of capitalism with the aim of an alternative search to the current system. Not a critical perspective within capitalism, which allows new monstrous mutations and not forgetting that capitalism, has been shaping itself through different 
coincidences and causalities, manipulated by economic power and for its benefit, in short, a change of model, not a change within the model.

The capitalist system in its construction process for more than 500 years, originating in the appropriation of a large monetary mass from the USA, generates certain behaviours and specific bases throughout its development - appropriation, dispossession, slavery, speculation, inequality, precariousness, multiple social costs, etc. These permanently increase the concentration of wealth in a smaller number of people, not only at the level of a locality, or of a specific country, but also worldwide (Rivera Vicencio, 2018, 2019).

Throughout this process, capitalism, until the 21 st century, is building a new governmentality (corporative) ${ }^{1}$, that Foucault describes perfectly in his books and in his classes at the Collège de France, mainly in the academic years 1977-1978 and 1978-1979. ${ }^{3}$ This governmentality intertwines different manifestations of power, “... its objective is the population, the political economy as a major form, as a fundamental technical instrument of the security devices" [Castro, (2011), p.177]. As “... a central phenomenon in the history of societies, it is the intersection between power relations knowledge with strategic relationships and the results of their interaction, that manifest themselves in a massive and universalising form of domination of a group, a caste or a class, together with the resistance and revolts that this domination encounters" [Rivera Vicencio, (2012), pp.747-748; Foucault, (1994), p.242].

Capitalism, by building this new governmentality, until it reaches the current corporate governmentality, sustained in the very orientation of power - knowledge, constructs a discourse, establishes certain disciplines and controls; it models a certain 'ethic' and develops its pillars in which it will be sustained, like the evolution of knowledge of science and, in particular, of economics. "To the extent that economic theory was accepted as a social theory, it 'became true' as a set of performative statements, thus revealing its essentially rhetorical nature as a persuasive instrument of social construction" [Streeck (2017), p.100].

In the multiple pillars on which capitalism is sustained, the following mainly stand out:

1 The dominant discourse, exercised through the control of the media, both scientific and news.

2 The security devices of the war industry, armies and security organisations as an instrument of the defence model and, in turn, an instrument of repression against any manifestation of resistance, and as an instrument of appropriation of resources and subjugation to plundered populations.

3 The economy and, mainly within the economic discourse, the monetary system.

However, these three pillars fundamentally rest on money transformed into capital and a means of appropriation that allows the appropriation of media, universities, 'scientific' magazines, the arms industry, the support of armies and 'security' organisations or repression.

Therefore, it is money, or better expressed, the accumulation of capital, which allows the establishment of a model of concentration of wealth and permanent appropriation, together with an entire legal structure in accordance with the appropriation model, that is to say, a capitalist legality model, also made up of the same money resources.

The most important general aspect to highlight is that both for international money and for national money, $97 \%$ of the money is created through private banking through 
debt-money [McLeay et al., (2014), p.2; Robertson and Bunzl, (2003), p.19; Rivera Vicencio, (2016b), pp.23-24].

Finally, the situation has been aggravated by the pandemic in which the world finds itself, which has exposed the inefficiencies of the capitalist model with privatised health systems, privatised nursing homes and dependence on the absolute international trade of the simplest sanitary elements, among many others. Together with the speeches of different interlocutors of the model who have wanted to prioritise the economy over the health of the population they have, unfortunately, ended up claiming a greater number of lives. Even in their inability to solve their own internal problems and to take measures in favour of the lives of their own citizens, they have sought to blame third parties for their own ineffectiveness.

\section{International money}

Since 1971, after the abandonment of the gold standard, the international exchange currency imposed is the dollar, starting with the agreement to trade oil only in dollars. The international currency becomes a mechanism of submission and control. Domination is no longer through colonisation but is exercised through entrenched monetary interests, transforming the international monetary system and its mechanisms as a tool for pressure and imposition of certain policies in accordance with the prevailing model, both directly and through international organisations controlled by the empire.

When the fragmentary currency disappears and debt-money prevails, a series of fundamental changes take place in the monetary system. You can create all the money-debt that is necessary for the appropriation and/or dispossession of companies and public resources, which, added to the dominant discourse, initiates the privatisation process worldwide [Rivera Vicencio, (2019), pp.49-53].

This process of submission through money-debt not only affects underdeveloped countries but also affects developed countries. The enormous levels of debt that individual countries accumulate and that continue to increase, mean that it will be the creditors who make the decisions, although they have been doing so for quite some time. Without forgetting that the FED, or the equivalent of the US central bank, is a private institution, that is to say, those who issue the international exchange money and the backup currency are private banks [Rivera Vicencio, (2016a), pp.81-84].

Foreign loans and foreign investment impose a set of conditions that end up imposing total domination and make countries vulnerable to sudden capital flows. Falling into the IMF trap means falling into austerity policies, including the elimination of subsidies, reduction of wages, increased corporate profits and the privatisation of public industry. On the other hand, the misleading GDP measure, which does not consider transfers to transnational's abroad is clearly an optical illusion of a country's wealth, the same as GDP per capita. The money that flows abroad in 'developing' countries by way of interest payments is much greater than the loans that flow from the first world [Hodgson, (2015), p.274].

That the USA follows the path of unstoppable debt is their problem but since they have imposed their currency worldwide, it turns out to be everyone's problem. Due to it being possible to produce the necessary changes in its monetary policy, the only solution is to abandon its currency as a medium of exchange and as an international reserve. It is 
the bonds sold abroad that finance its party. US banks have been bankrupt since the late 1980s and have continued to be given oxygen through greater indebtedness with transfers from public to private to the present day. This also happened in the 2008 crisis with all developed countries and some underdeveloped countries. Regarding the alternative to the gold standard, “... it is not a dollar standard created and administered unilaterally by the USA alone but a truly international standard, which requires joint decisions and administration from all participating countries" [Triffin, (1968), p.201].

It should not be forgotten that this greater indebtedness of the countries is transformed into a higher payment of taxes to pay the interest on the debt or a reduction in the services that the state provides to its population, whether public health services, free education, improvements in pensions, etc. and therefore in greater precariousness for its population.

The financial bubbles (over-valuation of assets) were the result of periods that this gold standard had been abandoned. This does not mean returning to a gold standard since private banks will continue to violate their standard and therefore will continue to create new bubbles in different sectors of the economy. Even the value of gold itself in the market is a value manipulated through future contracts, just like many other metals and merchandise in general.

The crisis in which the dollar is found, the use of the dollar as a tool of geopolitical pressure, with embargoes on different countries and blockades that limit their transactions, the high level of indebtedness of the USA, the trade war started against China, the high costs of maintaining its military bases in the world, among others, produce a great rejection worldwide and surely new commercial alliances will be developed that will leave the US out or it will be just one more currency, among many and of equal or superior economic and military capacity. All this is causing the generation of monetary alternatives other than the dollar and the parallel generation of a SWIFT system (Society for Worldwide Interbank Financial Telecommunication Society for Interbank and Worldwide Financial Communications) dominated by the USA. This is how many countries are trading oil with currencies other than the dollar and a slow, but constant increase in international transactions has been generated in currencies of the countries themselves, as is the case of China and Russia, and these in turn with other countries [Rivera Vicencio, (2019), pp.63-66].

The major aspects of international exchange and the use of exchange or reserve currencies are carried out through currencies accepted in special draft deposits (SDR). This type of asset created in 1969 by the IMF, consisted of a value equivalent to a certain amount of gold. Then, after the collapse of the Bretton Woods system in 1973 and the imposition of the dollar worldwide, it was transformed into a set of different international currencies. As of the 1 st October 2016, the currency weights were $41.73 \%$ for the US dollar, $30.93 \%$ for the euro, $10.92 \%$ for the Chinese renminbi, $8.33 \%$ for the Japanese yen and $8.09 \%$ for the pound sterling. Although these currencies suffer positive or negative fluctuations, the next revision will be made no later than 30th September 2021. The value of the SDR is determined daily in dollars, depending on the fluctuation of the exchange rates quoted on the London market. ${ }^{4}$

Some effects of the monetary flows to be highlighted for the purposes of this document are: 
- A large part of the international flows are carried out in dollars, with the exception that some countries in recent years have been carrying out their foreign trade operations in their own currencies.

- The dollar is a debt currency, that is to say, without more support than the debt itself when it was issued.

- The FED is a private institution.

- The trade balance of the USA is in deficit and growing from 1968 to date, with the only exceptions of the years 1970 (0.07\% of GDP) and 1975 (0.18\% of GDP). In 2019 its deficit was $4.31 \%$ of GDP $^{5}$ and in the last 20 years its average annual deficit over GDP has been $4.94 \%$ annually.

- What was stated by Triffin 6 in the 1960 s, later known as the 'Triffin dilemma' refers to the conflict of interest that is created, when a currency serves as a world reserve and the objectives as an issuing country and the international objectives for countries, causing tensions between their national and global monetary policy. The USA imposed its criteria through blackmail, using the IMF as a tool, an institution in which it had a greater weight in its vote together with Great Britain [Triffin, (1968), pp.117-143].

- Another problem is that "the bulk of the American economy, on which its growth has depended, has been characterised by stagnation or even by the decrease in income of the majority of the population, and by not having existed any engine of growth coming from new investments, whether public or private" [Gowan, (2010), pp.192-193]. This is because "... there was a shift of power from production to the world of finance. Increases in industrial capacity no longer necessarily meant an increase in per capita income, as did the concentration of financial services ..." [Harvey, (2007), p.40], moving from a productive domain to a financial domain world, supported by the dollar debt. In short, towards a speculative financial system, as shown by all the crises of the last quarter of the 20th century and the crises of the 21 st century, all with global repercussions.

- Another very relevant aspect is quantitative easing (QE), a monetary policy that injects money into the economy at interest rates close to zero. This new monetary mass does not enter the real or productive economy, it remains in the economy of large companies with a clearly speculative role, constantly overvaluing financial assets and feeding a new bubble. In turn, these overvalued assets are transferred to the real economy through pension funds, among others, and then make these assets fall, assuming the loss of pension funds or investments of individuals or small and medium-sized companies. These excessive flows of currency are also used by the directors of these large companies to buy back their own shares making their value increase fictitiously and extracting personal benefits from the stock increase [Rivera Vicencio, (2019), p.60]. 


\section{National money}

Within many countries, bank loans for productive activities are almost non-existent, except for large corporations that operate in the country, banks have become intermediaries in the sale of different types of articles, cars, household appliances, telephones, etc. which then associate and oblige an insurance company from an associated company. They no longer fulfil the function for which they have been created and accepted by society, they are complex speculative machines and commission agents in the sale of complex financial papers, commission agents in the channelling of state loans (resources obtained by the State from abroad) to certain sectors for reasons of national emergency, owners of real estate, and speculators in all the activities they carry out.

The banks that were being formed through the imposition of legislative measures to protect their fraud, through privileges granted by the political power at present and historically, in exchange for favours, through the privilege of enjoying oligopolistic positions, granted and maintained by this same political class, etc. (Rivera Vicencio, (2019). Today, not before, under their operating system, they are not essential for society, since much of their time and efforts are channelled to speculate to generate greater wealth for their managers and shareholders and no longer as a facilitator and channel of resources to the productive system (money supply).

Capitalism boasts of the increase of goods in the economy, despite the repercussions of this productive increase. This productive increase, together with the social costs of high production levels, associated with the precariousness of the system itself, "generated additional precariousness, such as the indebtedness of families and a new decrease in their disposable income through payment of interest for the consumption they make. This also generates a greater dependence on the real economy, on the financial economy, already predominant through 'debt money" [Rivera Vicencio, (2019), p.57]. "The action of the debt does not only consist in the manipulation of enormous amounts of money, in the sophisticated games of financial and monetary policies; it also informs and configures the techniques of control and production of the existence of users, without which the economy would not have dominion over subjectivity" [Lazzarato, (2013), p.159]. Added to this is 'the spying on the private life of the applicant' for credit, it is the action of 'mistrust towards the poor, the unemployed and precarious workers', generated by the capitalist economic model itself, 'all cheats' and 'potential profiteers', where 'hypocrisy and cynicism are the contents of the social relationship' (Lazzarato, (2013), pp.158-159).

Debt has fallen on the population with fewer resources, including the purchase of basic products, due to the low income they receive. In other words, a triple figure of appropriation of work income is introduced into the system. First, the worker does not receive a fair salary for his performance, the surplus value is extracted from him, second, he must pay a higher price for the products charged with interest, an additional surplus value is extracted and third, the State must apply more taxes for the payment of the debt that it acquires to finance its precarious structure, causing a greater precariousness of the worker. Streeck (2017) from a more structural perspective expresses it as the 'consolidating state' , where: 
"Citizens lose out to investors, citizenship rights are drowned out by demands for commercial contracts, voters are below creditors, election results are less important than bond auctions, public opinion matters less than interest rates, citizen loyalties less than investor confidence, and debt service crowds out public services." [Streeck, (2017), p.153]

This is the relationship that exists between the economy of large companies and the real economy, illustrated in Figure 1, which details the monetary flows that are generated within a country.

Figure 1 Relationship between the big business economy and the real economy (see online version for colours)

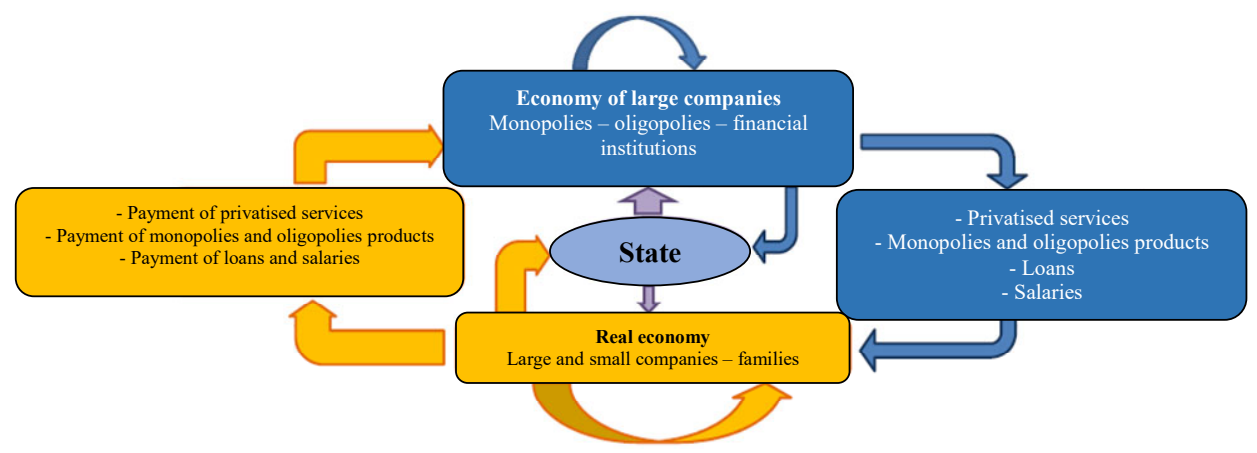

Source: Personal design

The product flows, services and money that occur within a country and schematised in Figure 1, where the thickness of the arrows represent monetary flows and can be summarised in the following:

- In both economies, there are internal flows that do not directly affect the relationship between them but they affect price levels within each economy, generally generating greater flows from the real economy to the economy of large companies.

- The State transfers resources and collects resources from both economies; however, the collection that the State carries out is much higher than the real economy, than the economy of large companies. In addition, it does not capture taxes from large companies that divert their profits to tax havens.

- The transfers made by the State to the economies are also unequal, since in the face of crisis it has always been the State that has rescued large private companies (the financial system). In the period of the privatisations of public companies, huge sums of money were transferred through future income and monopoly privileges.

- The products and services that are transferred to the real economy from the economy of large companies have monopoly or oligopolistic prices, extracting a surplus value from the real economy, either directly to the workers or indirectly through a higher cost that occurs in families, small or medium-sized companies.

- The purchase of products and services that the real economy makes can also be burdened by direct financing that large companies can make, that is to say, prices 
increased with interest, which generate a greater monetary flow from the real economy to the economy of large companies.

- The financing received by small and medium-sized companies (extraction of surplus value), in addition to causing an increase in prices within the real economy, generates a greater monetary flow to the economy of large companies.

- Under this existing relationship system between the two economies, there is always a greater transfer of monetary flows from the real economy to the economy of large companies, causing a greater concentration of wealth and greater precariousness in the real economy, causing a growing inequality over time. Flows that also include the transfer of companies from the real economy to the economy of large companies (market concentration).

\section{Money and interest}

The vast amount of literature on money and interest is based primarily on money as a commodity. There are minimal exceptions throughout history that did not see money backed by some merchandise. The most common of the commodities that backed money were silver and gold.

Hence, the general acceptance and the economic theoretical treatment of money was always like money backed by some merchandise; money fulfilled the function of exchange value and the function of use value.

This situation or double function of money makes its accumulation transform it into capital (circulating capital) and, at the same time, subjects it to a price for its use, which, unlike other goods, does not extinguish with its use. It allows even more to its owner and this money is increased, through the facilitation of its use with an interest surcharge.

Hume in 1752 in Volume III of the 'Moral, Political and Literary Essays', states that, "money is not, properly speaking, a commodity, but the instrument with which men agree to facilitate the exchange of a commodity on the other" [Hume, (2008), p.93] 'and it only serves as a method of evaluating or estimating them' [Hume, (2008), p.96]. Hume's writings served as the basis for the "quantity theory of money' 8 and have been a source of inspiration for great economists in history, among many others, Lucas, Nobel Prize in Economics in 1995, who based his lecture 'monetary neutrality' in the essays 'about money' and 'about interest' by Hume (money neutrality).

Later in 1776, Smith $(2017$, p.72) in the 'wealth of nations', in the same line as Hume states, "it is evident, therefore, that work is the only universal and precise measure of value, or the only standard by means of which we can compare the values of different merchandise at any time and place".

Rightly Marx (1976, p.212), following the guidelines of Hume and Smith, refers to the fact that "money is now objectified labour, whether it has the form of money or that of a particular commodity".

By withdrawing commodity money from circulation to treasure it, its capacity for exchange value is eliminated and, therefore, reducing the capacity of the productive economy, since it reduces the possibility of exchange. Therefore, "as long as money remains a treasury, it does not function as an exchange value, it is merely imaginary" [Marx, (1976), p.204]. "Retired as treasury, it does not function as exchange value or use 
value; it is dead, unproductive treasury" [Marx, (1976), p.205]. This is the accumulated money that is then transformed into capital (circulating capital).

In the origins of capitalism, the reduced volume of transactions and the reduced quantity of commodity money (silver and gold) in Europe, allowed a minimum accumulation of capital. The appropriation of silver and gold from the USA allows capitalism to develop in Europe, by spreading this monetary mass throughout the continent (Rivera Vicencio, 2018).

In this way, capital is transformed into the power to acquire a certain work capacity of others. The sale of work is no longer objectified work transformed into merchandise, it is an "exchange between money and work in the specific exchange $\mathrm{M}-\mathrm{C}-\mathrm{M}$ " in which the exchange value itself is set as the objective of the exchange, and where the value of acquired use is immediately use value for exchange value, that is to say, use value that puts value" [Marx, (1976), p.218].

Reversing this analysis, it could be stated that true capital is the capacity for work, the only source with the capacity to transform a resource into a commodity. It could also be expressed that accumulated capital is unpaid work capacity, since this accumulation of capital has only been possible, paying a lower value for work, in order to extract surplus value to accumulate it and transform it into capital.

On the other hand, the variation in prices, the product of natural and non-speculative effects, will cause the price of goods to change in the face of greater or lesser production of goods and services in the economy, since each of these goods and services has a built-in given amount of work and the value of the work is the same. Therefore, a lower production of goods or services, for example due to a drought, will raise the price of crops, since they will have to pay the same amount of work as if there had been a good year in crops [Smith (2017), pp.100-101].

In this same direction, capital in turn generates an interest which "is initially, and in reality continues to be only that part of profit, that is to say, of surplus value, of the acting capitalist, industrial or commercial, to the extent that it does not use its own capital, but rather the borrowed capital, it must pay the owner and lender of this capital" [Marx and Engels, (2017), p.427]. In this way, the profit is broken down into two parts, the profit necessary to pay the interest of the lender and the participation in the profits of the acting capitalist, whether industrial or commercial [Marx and Engels, (2017), p.430, pp.432-433].

Interest becomes part of the profit rate and if the profit rate is extracted from the worker's capital gain or from a lower payment for his work, in short, the interest is paid directly by the worker through a lower remuneration for his work.

Furthermore, the capitalist who works with his own capital, like the lending capitalist, also demands an additional profit for his own capital, as if he were his own lender, together with a business rate of profit, which would correspond to him as an active capitalist [Marx and Engels, (2017), pp.432-433], "interest is a relationship between two capitalists, not between capitalist and worker" [Marx and Engels, (2017), p.440]. In this way, it is "money that creates more money. It is the original and general form of capital, reduced to a meaningless compendium" [Marx and Engels, (2017), p.451].

In this way, the value of the merchandise has incorporated the appropriation of the surplus value in the concept of interests and business profit, be it industrial or commercial. Therefore, the money extracted from circulation and transformed into circulating capital, both for the moneylender and for the industrial or commercial 
entrepreneur, has not only reduced circulation and exchange but has also extracted a greater surplus value. Now if we add that, lenders normally enjoy oligopolistic market power, which means that they can extract a higher 'price' (interest) for money, the greater the appropriate surplus value.

The accumulation of money becomes a deprivation of exchange, its monopolisation or oligopolisation, depriving money of its essence for which it was created - as a means of exchange. The monopolisation or oligopolisation of money does not allow money capital to flow to production, much less to sustainable production, understood as production that is responsible for life.

In the current situation, where money is issued in huge volumes, especially in the USA and countries that are applying QE, the interest rate will tend to zero. But this interest is only applicable to large companies and, within these, financial institutions. This interest rate close to zero, is not transferred to production or consumption, that is to say, it does not reach families, or small and medium-sized companies, for these the interest rate is much higher, the money stays in the economy of large companies in a purely speculative role, to obtain greater benefits. Marx expressed it in the following way, "if a disproportionately large part of the capitalists transformed their capital into money capital, the consequence would be an enormous devaluation of money capital and a tremendous fall in the interest rate; many would immediately be unable to live off their interests, that is, they would be forced to reconvert themselves into industrial capitalists" [Marx and Engels, (2017), p.435]. Yet Marx did not consider the possibility that these capitalists became only simple speculators and did not transfer those interests close to zero or zero to the real economy. "For this reason Aristotle considers that the form of circulation C-M-C, a movement which he calls economic and in which money only functions as measure and currency, is the natural and rational form, while he stigmatises the form M-C-M, chrematistics, as unnatural and counterproductive" [Marx, (1976), p.195].

\section{Inconsistencies in the current monetary system}

The multiple incongruities that the current monetary system presents can be classified as those of a general nature that affect the system as a whole, those with effects on international exchange currencies, and those that affect national currencies.

In the first general inconsistencies and with effects on the entire monetary system are:

a To continue treating money as merchandise when it does not have any support in any merchandise.

b The privilege of private and profit-making institutions to create debt money remains.

c Charging interest on debt money created by a private institution. This is equivalent to creating a means of purchasing future work capacity from scratch and appropriating this future work capacity if more support than the privilege of issuing debt money.

d The power to generate a tool for the appropriation of surplus value through the interest charged in the production process and incorporated in the profit rate.

e The permissiveness that these issuers of debt money enjoy oligopolistic positions, both at international level and national level. 
All these senseless national and global effects, by themselves, make it necessary to adopt profound changes in the money generation system (money supply).

In addition, we find inconsistencies at the international monetary system level, such as:

a The first of these senseless effects, can be manifested, with the question that De Gaulle posed at a press conference in February 1965, referring to the international reserve currencies of Great Britain and the USA; "Why should the richest countries in the world be allowed to monopolise the benefits of the creation of international reserves to finance their own deficits?" ... "If new reserve assets are to be created, this must be the result of joint decisions with agreed purposes, and to replace - rather than simply complement - the privilege currently enjoyed in this regard by the two Anglo-Saxon currencies, economically irrational and politically unacceptable" [Triffin, (1968), p.122]. If this already happened in the 1960s, the incongruity or nonsense is even greater, than the US imposed the dollar as a reserve currency and international exchange in the following decade (elimination of the gold standard).

b For more than 50 years, the world finances the deficit of the US trade balance or the dollar, together with a public deficit for more than 40 years, with few exceptions from 1998 to 2000, where a large part of this public deficit is oriented to the arms industry.

c What sense does it make to continue using the dollar as a reserve and international exchange currency, if the one who issues the currency is a group of private financial institutions (FED) when the current world conditions are very different than when the dollar was imposed.

d What sense does it make that the vast majority of international trade operations or international financial flows have to go through the SWIFT system, controlled by the US and that in turn generates a series of additional costs to these operations when today there are sufficient technologies to avoid these additional costs.

e The negative effects on the rest of the world economies by using an international exchange currency which in turn is used internally in the US with contradictory monetary policies (Triffin's dilemma).

f The negative effect of using the dollar and its operating channels, on the economies, due to the effects of arbitrary and clearly political blockades in different countries or just because of the possibility of blockade, if the person in charge of the shift disagrees with the internal policies of some particular country.

g The excess money supply issued by the USA, through different mechanisms and direct injections to large companies, causing inflation of various assets (crisis), causes negative global effects, often transferring losses to other countries and/or the real economy.

$\mathrm{h}$ The negative effects on many of the world's economies because of the imposition of policies by international organisations, such as the IMF or the World Bank, dominated by the USA, as a result of the financing that the countries require.

i Finally, and among others, the effects on the economies due to the manipulation of the value of internationally tradable assets or that serve as a means for international 
operations, with internal effects in the countries, such as the manipulation of the price of various metals, manipulation product prices or interest rate manipulation.

These inconsistencies, moreover, are also made by the different international reserve currencies, to a greater or lesser extent, that is to say, all those that make up the SDR basket.

Finally, the inconsistencies that can be pointed out in the economies at the domestic level because of their local currencies are:

a The privilege of a small oligopolistic group, national and international, that issues debt money in the national currency.

b The increase in the appropriation of surplus value, through the interests applied internally in a country.

c As detailed in Section 3. of this article, the monetary flows that occur domestically, favour the concentration of wealth, under the current system of monetary creation, which in turn increases inequality and precariousness.

d Products and services become more expensive through the application of interest for the purchase of goods, whether durable or not, and as additional financing to workers, as a result of low salary levels. That is to say, in an escalation of double appropriation of surplus value by interests applied to production and consumption.

e The fact that these oligopolistic financial institutions channel credits to sectors where their returns generate greater benefits (usually speculative) and not according to the country's priority productive and service needs.

f Credit contraction in times of economic crisis. Given the adjustments that these institutions must make, due to the excess of monetary mass that they have injected into the economy, they must contract the money supply in moments of crisis (crises caused by themselves).

g These financial institutions that create debt money, also block any policy other than those imposed by them on state banks that may exist. That is to say, they impose a certain operation that increases profits through the collection of commissions that standardise in the system or the collection of abusive interest rates and blame a State body for unfair competition, if it dares to apply fair prices.

$\mathrm{h}$ They generate a benefit of a debt money, which in real terms does not exist.

i The interest charged does not exist, not even as debt money, and therefore the only way to extract them from the economy is through the appropriation of surplus value, but generating more debt money, which covers this interest.

j Furthermore, since they can issue debt money without control, the institutions that create debt money can cause monetary instabilities in the internal economy without any control and without repercussions. For example, creating uncontrolled inflation, stopping credit when the country needs it or financing speculative sectors. In short, they can control the internal economy based on their own particular interests.

All these inconsistencies in the monetary system as a whole, force a rethinking of the current system to be carried out but not only to make small corrections that leave everything the same but also to make profound changes. 
In the crisis of 2008, as a result of the overvaluation of assets due to the increase in the monetary mass, is what happened to the value of housing, not only in the USA, but also in other parts of the world. In the world, as in Spain, in the most shocking moments of the crisis, several world leaders spoke of the refounding of capitalism, to later leave everything worse than before, transferring the bank rescue to society.

This new crisis, no longer economic but sanitary, has exposed the great deficiencies of capitalism and the neoliberal model or corporate governmentality, not only because of the effects that the privatisation of the health systems has had on the population; for example, hospitals, nursing homes, production systems linked to health, etc. However, large companies, not only the financial system, as in the previous crisis, knock on the door of the State to be rescued; that is to say, more than usual, the privatisation of profits and the socialisation of losses. Furthermore, at the time of this new health crisis, the neoliberal system was already in crisis. It presented an overvaluation of its assets, whether they be shares, derivatives and the real estate sector in large cities. All these overvalued assets, even if the injections of debt money are increased, will not be able to withstand, since the level of activity will decrease sharply and the restart will be slow, as many leading economists and international organisations predict.

Simultaneously, in the population there has been an increase in the appreciation of what is public, either because in those places where the privatisation of health services has been more pronounced, the effects on human lives have been greater. Also, because the one that is rescuing people, through different kinds of aid, has only been the state, while the vast majority of private companies have turned their backs on them, especially those of the economy of large companies, which even rudely request aid from the states.

Regarding the financial system as a whole, it will surely suffer sharp increases in delinquencies and if this pandemic is not overcome in the very short term, the situation of these institutions will become more complicated. The states will also have a strong work in the rescue of the economies, which will not only be a social demand, but also a business one and which will open a huge door to produce profound changes in the system.

In summary, a greater appreciation of what is public by the populations, the crisis that the financial system as a whole will suffer and a transversal demand for State intervention generate a turning point to make the corrections that the monetary pillar of the economy is corrected. Hence, the approach of this article and this proposal of the following sections.

\section{Reflections about the economic theory}

The initial reflection that should be done, prior to addressing the currency proposals, should be to understand capitalism as a historical formation, the product of power struggles and resistance, as well as coincidences. Where the winner has imposed his criteria and has written history, but also, has justified its conformation through science, in this case economic science. In turn, it has been considering and interpreting the contributions of different authors, only in those aspects that have been favourable to the dominant power.

Capitalism in its own makeup, replaces the invisible hand of Smith, by 'the Company' as the regulatory body of the price mechanism (Ronald Coase). Giving all 
autonomy to this new entity, with religious enthusiasm and glorifying the market, with a single purpose, that of 'maximising profits' (Rivera Vicencio, 2014). Under these premises, capitalism is generating the economic, legislative, political instruments, etc. so that the company can maximise its profits, which is only possible to achieve, when it enjoys a monopoly position or, in the best of cases, through an oligopolistic or cartel position, sharing with others the dominant position of the market. Work that capitalism exercises, through the appropriation of the wealth of others, and fundamentally, through the appropriation of surplus value, so that with that wealth it can absorb other companies and achieve a dominant position in the market. That is to say, capitalism brings in its structure, the concentration of wealth, to achieve the maximisation of benefits, inequality and precariousness, product of the appropriation of surplus value.

All this, despite the strong criticism of monopoly or oligopoly, of the classics of economics such as Adam Smith, David Ricardo, John Stuart Mill and many others, for highlighting the most cited in defence of capitalism. At the very least, it is very difficult to understand that the currencies in international exchange - issued by private financial institutions - enjoy a monopoly or oligopolistic position, like the currencies that serve as international reserves (SDR) and only five countries have the right to issue them, even if one of them is the predominant one (dollar). As also at the national level, a small group of banks, enjoying an oligopolistic position, issue the local currency used in the exchange.

However, even more serious is that the pillar of economic science is based on such poor bases, such as the argument that only the market will act as a natural regulator, to avoid the existence of monopolies and/or oligopolies, such as the 'theoretical standard economy model' (MEe) and money transformed into capital.

First, in the case of MEe, starting with the adoption and "use of typical concepts of orthodox, mainstream or standard economics such as 'imperfect information' economics of imperfect competition' or 'market imperfections', to refer to aspects that are in fact normal, central in the functioning of our market economies" [Vergés, (2019), p.14]. But it is not only a semantic issue, it is a much deeper aspect, it is discourse, discipline, control and an 'ethic' that is shaping a new governmentality, capitalist governmentality, which also shapes science, according to Foucault. Here are some examples taken from Vergés (2019):

- Given the "inexorable competition, each company will end up selling the product at a price equal to its marginal cost, which in turn will be equal to its average cost; that is to say, it will not obtain any benefit" [Vergés, (2019), p.22]. It would be enough to look at the income statements of any company, to prove otherwise,

- Productive assumptions, 'Ricardian', of diminishing returns:

a 'from a certain size, the company becomes inefficient due to being 'too big, ungovernable'

b '(always for any good) there is a factor of (fixed) limiting production' [Vergés, (2019), p.39].

- Both assumptions threaten reality, in general the opposite can be observed, companies grow as much as possible to the extent that their sales allow them and when one of their resources may be limited, as may be the case of primary resources, buys other companies, installs and buys resources in another country, appropriates 
them, etc. Moreover, it is enough to see that in most countries the primary sectors are dominated by large companies [Vergés, (2019), pp.39-43].

In this way, capitalism generated axioms, which maintain a dominant economic discourse in the economic profession, of:

a 'a system basically in equilibrium, or that tends towards it in a 'natural way', where the 'free market results of a system of automatic balances' [Vergés, (2019), pp.157-158]. But this in turn has repercussions:

b 'in legal regulations and public decisions'[Vergés, (2019), p.158]

c in assuming competition as a myth, and indisputable in public decisions [Vergés, (2019), p.159], which affects not only the banking market but also health education and all markets.

These axioms are in which the banking and financial market is supported, where the discourse imposes that the intervention of a public bank in the market would make 'unfair competition' or where a situation of dominance of 'market on an international scale turns out not to be considered 'a distortion of competition in the market', worthy of attention in this or that country' [Vergés, (2019), pp.160-162].

Secondly, about the money transformed into capital. The economic theorist about money, based on Smith, refers to money 290 in 'The Wealth of Nations' but none of them considers money without the backing of a commodity. It assigns money a double role - of use value and exchange value [Smith, (2017), p.62], that is to say, a commodity that can be exchanged for other commodities. Where goods contain a certain amount of labour which is exchanged for what is supposed to have an equivalent value [Smith, (2017), p.65], but without any doubt, Smith (2017, p.66) refers to it as commodity money. In other words, a commodity with a more general equivalent is sought, to replace bartering, but keeping in mind that "work is the only universal and precise measure of value, or the only standard by which we can buy the values of different commodities at any time and place'.

Smith (2017, p.385) also refers to money with fractional reserve, 'when their clients ask for money, banks generally advance it in the form of their own banknotes' but these banknotes, despite not being a merchandise itself, represented an amount of merchandise equivalent to the amount registered on the bill and banks had to have a certain amount of money in their boxes to respond to requests for money and the backing of merchandise, such as gold. This made saving so important as a means of responding to requests for money. It also gave banks the power to create money out of thin air, which goldsmiths already did.

Another element to highlight in the money is that when interest is applied for a loan, the legal bodies that protect the lender are generated, even if they are not lending merchandise money directly, but an equivalent to it, but nonexistent, the banks created money, with a small portion in reserve. This was associated with excess money issuance by banks, which led to numerous bankruptcies and losses of money for savers. There are extensive cases in economic history. Once private banks are given the possibility of issuing money without real backing for the merchandise, control of the economy is handed over to these private institutions, leaving the economies subject to over-issuance of money, which then causes crises. Nowadays, these large banks are considered too big to fail and although they are once again rescued with public money and pass under the 
control of the state (the 2008 crisis), they are once again in private hands as part of the myth of public decisions.

From these central elements of money, Smith (2017, p.68) constructs the difference between the real price and the nominal price of labour, a difference that Marx (1976, p.92) will call surplus value. Also on this basis, the concept of capital is built on a commodity (usually metals such as silver and gold) that is hoarded, that is to say, withdrawn from circulation. 'The derivative of capital not by the person who uses it himself but lends it to another, is called interest or use of money' and, in this way, the economic concept of interest arises.

From these elements, if we compare it with the current situation, where money is created by an oligopolistic group and without any endorsement of any merchandise, the money thus issued could be the means of exchange to acquire merchandise already manufactured, but it also contains the possibility to buy future work, that is to say, work not objectified. This without more value than the cost of paper and printing, and not even that, since much of the money in circulation is virtual, accounting entries. Seen from this perspective, it is either a total nonsense or a huge scam. Therefore, after the abandonment of the gold standard at the beginning of the 1970s and from the end of this decade, private companies were able to buy public companies, usually with many investors and financial institutions (privatisations, including natural monopolies). It is also worth noting that the change in the discourse on saving ${ }^{10}$, to a discourse on consumption, since the credit (debt money) possible to issue, allows the capture of non-objectified work, in the case of the loan applicant, that is to say, future work through the collection of interest and objectified work, by exchanging this money for merchandise. This in turn has global repercussions, which base the model on constant and perpetual growth, which is by no means sustainable over time, expressed in other terms; the money model of the system is linked to a production model without limit, which in turn links from an ideological aspect, well-being to greater consumption.

One of the fundamental bases of neoliberalism (corporate governmentality) is the formation of the monetary system, the possibility of creating debt money which facilitated and accelerated the process of appropriation and concentration of wealth, causing the increase in inequality, of precariousness and the increase in social costs, the product of a growing productive system oriented solely to consumption (Rivera Vicencio, 2019).

\section{Neutrality of money and national and international proposals}

\subsection{Neutrality of money}

Adam Smith discards a different alternative for money, in the face of already existing proposals, and that he himself cites as the alternative of Mr. Law who proposed the creation of 'a special bank that would issue notes for an amount equivalent to the value of all the land of the country'....about the "project is explained so fully, clearly and neatly by Mr. Du Verney in his examination of Mr. Du Tot's Political Reflections on Trade and Finance, that I will not give details about them here" [Smith, (2017), pp.408-409]. However, it devotes a large number of pages to bank fraud, due to the over-issuance of banknotes, as well as to the relationship between the moneylenders and the 'lords of the land' or the 'rural hidalgos' [Smith, (2017), p.450], in relation to credit risk, as it also 
makes very clear its position regarding the application of interest, even with respect to countries that prohibited interest on money by law [Smith, (2017), p.457).

Adam Smith, referring to the effects of the quantity of gold and silver appropriate from the USA and reaching Europe, quotes Hume $(2008$, p.454) as the person who had clearly explained the phenomenon and its effects. However, Hume (2008) had also clearly expressed his position on money and Smith makes no reference to this. Hume (2008) expressed this aspect in the following way:

"If there is no public bank, private bankers will take advantage of this circumstance, as goldsmiths formerly did in London or bankers do today in Dublin. Therefore, it must be thought that it is better for a public entity to enjoy the benefits of credit that will always find a place in every opulent kingdom. But attempting to artificially increase credit can never be in the interest of a commercial nation because it would bring it disadvantages, increasing money beyond its natural proportion to the quantity of labour and commodities and thus increasing the cost of merchant manufacturers." [Hume, (2008), p.95]

This paragraph quoted from Hume (2008) has two important components. The first component is the verification that economic science has been developed according to certain power struggles, and a certain 'scientific' knowledge has been imposed, with a certain discourse, which could have been very different if the development of a set of economic concepts and theories would have been based on this little paragraph, through resistance to power.

Foucault refers to the economy as:

\begin{abstract}
"An atheistic discipline is a discipline without God; it is a discipline without totality; it is a discipline that begins to reveal not only the uselessness but also the impossibility of a sovereign point of view, of a sovereign point of view on the totality of the State that he must govern. The economy removes from the legal form of the sovereign who exercises its sovereignty within the framework of a State what begins to appear as the essential part of the life of a society, namely, economic processes. Liberalism, in its modern consistency, began precisely when that essential incompatibility was formulated between, on the one hand, the non-totalisable multiplicity characteristic of the subjects of interest, the economic subjects, and, on the other, the totalising unity of the legal sovereign." [Foucault, (2012), pp.325-326] ... "Adam Smith's political economy does not limit itself to showing the extent to which mercantilism represented a technical or theoretical error. Adam Smith's political economy, economic liberalism, constitutes a disqualification of this political project as a whole and, even more radically, a disqualification of a political reason adjusted to the State and its sovereignty." [Foucault, (2012), p.328]
\end{abstract}

A proposal to reform the monetary system does not mean returning to the gold standard, it does not mean retaking commodity money and re-establishing support for monetary theory with all its inconsistencies, it means returning to the true origins of the economy and considering successful cases throughout recent history, regarding the creation of money to apply in this new proposal. Nor is it a matter of adopting social measures, charged to new credits or with a greater indebtedness of the states, such as applying a minimum vital income ${ }^{11}$, which as a transitory measure can be perfectly justified. This measure is likely to increase economic activity, but these resources will represent higher future taxes. The same can be done, but with associated interest costs, hence the consideration of a temporary measure. 
The monetary scenarios will continue to be those of national or internal economies and the scenario of the relationship between the economies of the different countries or groups of countries. This proposal therefore refers to a new national currency and a new international currency, which manages to correct the incongruities of the currencies and the economic imperfections, in what they call the money market, when there should not be such since it is only a medium of exchange, it only has exchange value.

But any proposal of a monetary nature must address a central and essential principle, such as 'the neutrality of money'. By treating the neutrality of money as a principle, he is referring to the fundamental foundation on which the entire rest of the monetary system will be built. This fundamental basis or neutrality of money is built on Hume's (2008) paragraph cited in this same section and prior to his approach to the neutrality of money. Thus, when many authors refer to the neutrality of money, they forget the basis on which it arises.

When Lucas (1995), posed in the following context the following question:

"This tension between two incompatible ideas - that changes in money are
neutral units changes, and that they induce movements in employment and
production in the same direction, has been at the centre of monetary theory at
least since Hume wrote. Though it has not, in my opinion, been fully resolved,
important progress has been made on at least two dimensions. The first is a
purely theoretical question: Under what assumptions and for what kinds of
changes can we expect monetary changes to be neutral?" [Lucas, (1995), p.248]

What is in the background is - who issues the money? And the answer is the quote from Hume (2008) in this section. What can be more neutral? That the state itself issues the money directly, without delegating it to third parties, who will prioritise for their own interests rather than for the interests of the population. It will only be enough to observe the overflowing issuance of money, through QE, aimed at covering the bad decisions of financial institutions, but also, many of these monetary resources have been channelled to speculation and not to production. The neutrality of money has been treated with a text out of context.

When McCandless and Weber (1995), also cited by Lucas (1995), provided evidence on the correlation between monetary growth and output growth for the period 1960-1990, this period should also be contextualised. During the period studied by McCandless and Weber (1995), the great transformation of the monetary system carried out in the 1970s cannot be ignored. This transformation that changes the support of the issuance of money, from the gold standard to debt money, generates a large volume of activity in the economy, through the enormous privatisation process in all parts of the world, issuing debt money to buy public companies. Countries by losing their sources of income and receiving large amounts, which partly repaid debts and the rest injected it into the economies of their countries, obviously generating more activity, all this despite the crisis of the 1980s. The results would be very different, if the study period were from 2000 to 2020 , where money continues to be injected into the world economy destined for speculation and not for production, where these resources are channelled to the overvaluation of assets, such as for example the repurchase of shares, the overvaluation of new technology companies, real estate assets, etc. The problem is not in the amount of money issued, but with the issuer's priorities and the maximisation of its benefits that it prioritises, over production growth. Hence, the results of McCandless and Weber (1995) also find a weak correlation for the OECD countries. 
On the other hand, Stockman (1996) for a period and sub-periods of 1950-1994 and Sargent (1986), arrive at inconclusive results on the correlation between monetary growth and output growth, for the same reasons as in the case by McCandless and Weber (1995). Many research works fail to confirm the neutrality of money and the correlation of monetary growth with the growth of production. They try to contrast real data with Hume's (2008) theoretical approach but without considering that the starting point is the wrong one, since the indirect intervention of the agent (contained in the real data) acts in an imperfect way. It is distorted; a product of the absence of neutrality of the money issuer, that is to say, the money is being created by private companies with their own objectives, not neutral for the economy as a whole.

From this starting point, other theoretical studies come to demonstrate the existence of this correlation but with the component of the non-existence of a private monetary system that makes the process of monetary issuance irrational (models without the intervention of the agent acting imperfectly). This is how the investigations of Samuelson (1958) and Lucas $(1972,1973)$ reach conclusions that largely confirm to Hume's (2008) approach. This Nash equilibrium is only possible without the intervention of an imperfect agent in charge of the money supply.

Now, from this perspective, the many times cited Phillips' (1958) curve could be subject to revision since it is based on an observation in the UK for a period of 1861-1957 [Rivera Vicencio, (2016b), pp.30-31], but for much of this period the Bank of England was a private bank from 1694 to 1946, but in turn, regardless of the nationalisation of the Bank of England in 1946, the money supply is issued by private bank companies, in a high percentage of the total, (Rivera Vicencio, 2016a), so that the distortion and speculation about the amount of money in the economy by these institutions in the period studied, would not allow a correct assimilation to the Hume's (2008) theoretical approach. Indirectly, in the study, the intervention of the agent that acts imperfectly is found.

Friedman and Schwartz (1963) in a study in the USA for the period 1867-1960, associate how a large contraction in the money supply is associated with depressions. This research can again show us the interference of an imperfect agent in the market, which by issuing more money than is necessary for production, and channelling monetary resources to speculation, will produce an increase in the value of some assets (bubbles), causing a crisis, together with the subsequent contraction of the money supply to correct the excess of money supply that caused the crisis. Both, contraction of the money supply and depression, are associated by the intervention of the monetary agent who is acting imperfectly.

In 1933, Hayek (2010) directly rejects the applicability of the neutrality of money, since, according to him, "it was created to be used as an instrument for theoretical analysis and should not, in any way, at least as a first instance, be used for a monetary policy" [Hayek, (2010), p.318]. Yet his denial, in addition to not making any great deepening on the subject is largely due to Hayek's (2010, p.320) own recognition because this made him unable to maintain what he had written before. However, it states that, "the relationship between the theoretical concept of neutrality of the money supply and the ideal monetary policy consists in that the probably most important criterion, although not the only one, to assess the precepts of this policy is the degree in that the latter is close to the former" [Hayek, (2010), p.319]. 
In this same quoted text, Hayek (2010, pp.219-220) makes an implicit recognition of the need for an ideal monetary policy which in no way can be carried out by institutions that have their own profit interests, which even more so in many cases are contradictory with a monetary policy ideal or at least have this orientation. So much so that a previous text highlights that, "It cannot be assumed that a central banking system is better prepared to avoid disturbances in the economy derived from excessive variations in the volume of available credit than a system of independent and self-sufficient commercial banks guided by purely business principles (liquidity, profitability)". Reality has clearly shown the opposite, the only entrepreneurial principle of the bank, maximising its profits, is incompatible with economic efficiency or with the efficient allocation of the money supply, since if speculation is more profitable, resources will be allocated to speculation, as has already happened throughout monetary history.

Both Hayek and Friedman, with a great ideological load, “... have blamed the imbalances and inefficiency of the monetary system on government intervention which, in turn, has influenced a greater liberalisation of the financial market causing greater imbalances to the existing ones and today we are in a spiral of wealth concentration" [Rivera Vicencio, (2016b), p.29] and, also, at a stage in history when the money supply assigned to production is much lower than the assigned to speculation. Friedman, through the plucking model, tries to reinforce his own myth about competition in the money supply market and the non-existent role of the State in this money supply; states that the growth of full employment is interrupted by an imbalance in the monetary policy applied by the governments [Alonso et al., (2011), p.78], forgetting that the state has a minimal participation in the money supply and its work regulatory framework on this market is almost non-existent.

Many authors have also ignored Knapp (1924), who in 1905 wrote, 'The state theory of money', which insisted on the monopolisation of money by the State and without a commodity money:

\footnotetext{
"The possibility of a monetary system without a hylic metal (an autogenic system) is easily overlooked, as it is very rare; but it actually exists. There is, as we already know, autogenic paper money; and though there is nearly always specie money (therefore hylogenic money) as well, the specie money, too, can be imagined absent, as will appear when we come to speak of the functional relations of the different kinds of State money." [Knapp (1924), p.85]
}

When returning to the background or starting point of the neutrality of Hume's (2008) money, the following aspects can be highlighted:

a The money must be issued by the State, avoiding the monetary speculation that has been demonstrated, both in the same text quoted from Hume (2008), as well as throughout history, and much more strongly since the end of the 20th century and in the first two decades of the 21 st century (inefficiency of the money supply).

b In this way the money that the state will inject the economy will be oriented towards production and not speculation (avoiding crises due to overvaluation of assets).

c The money injected into the public and private economy, through credit evaluations oriented to the welfare of the population, will naturally increase employment.

d The State will not issue more money than is necessary for the economy, therefore, there will be no excess money supply, and therefore, there would be no inflation. 
e The monetary distortions that could exist, through the financing for large-scale projects, could generate punctual inflation in the short term, with an impact on a specific sector, but not with general characteristics in the economy, or long-term.

f The State may prioritise the projects to be financed in depending on the needs of the country.

g The State may prioritise financing for small and medium-sized companies and families (e.g., mortgage credit, aid for single-parent families, aid for large families, salary for the person in charge of the housework, aid for part-time work, aid for teleworking, etc.)

h Currently, the State may direct the credit to import substitution, to economically and ecologically sustainable projects, to energy substitution based on fossil fuels, etc.

\subsection{Proposal of national money}

With all these antecedents, the proposal of local or national currencies and the proposal of an international currency can be developed, which has as its central axis the correction of market imperfections, whether they are monopolies and oligopolies in any sector of the economy, and mainly, the correction of the participation of imperfect agents in the creation of the money supply, which is the basis of the correction of monopolies and oligopolies.

Initially, when proposing a proposal, it should be noted that the creation of national and international currencies is nothing new; there are various approaches in this direction and some recent practical applications.

Among the recent cases to highlight at the level of local and national currencies, are:

1 Activities of environmental groups, such as the global barter network (La Red Global de Trueque-RGT), in this system merchandise is exchanged for vouchers that are later used to exchange for other products and/or services [Hodgson, (2015), p.333]. More than 30 different types of local currencies circulate in the USA; among them the Ithaca Hour created by Paul Glover in New York, and it consists of an exchangeable note for one hour of work or its value in goods and services. Very similar is the time dollar created at Columbia by Professor Edgar Cahn [Hodgson, (2015), p.334-335]. Electronic currencies can also be highlighted, such as the local exchange trading system (LETS), created by the computational expert Michel Linton [Hodgson, (2015), p.337-338] and today there are more than 800 systems based on LETS, both in Europe, New Zealand and Australia.

In this last group all types of virtual currencies that circulate today can be included, fulfilling similar functions.

Both Sweden and Denmark, through savings and loan companies, generate interest-free operations and function perfectly for decades, although obviously they are not designed to generate direct benefits, but rather benefits by obtaining interestfree loans (p.405). 
2 With national currency applications and recently, chronologically, Germany, China and Iran stand out.

Germany in July 1933 issued the MEFO bonds of the German Metallurgischen Forschungsgesellschaft mbH (Sociedad de Investigación Metalúrgica SL), which served them for job creation, rearmament and financing of public spending, without the need for new indebtedness, denying the possibility of financial world of profit. It is also known as 'Feder money', as it is based on the ideas of Feder, who stated in the words of Zarlenga (2002), quoted by Hodgson "that the state was the one that should create and control the emission of its currency through a national central bank, instead of being created by private banks" [Zarlenga, (2002), p.590; Hodgson, (2015), p.227]. Emry (1984, p.21) also quoted by Hodgson (2015, p.231), states, "Germany financed its entire government and war operation from 1935 to 1945 without gold and without debt".

The 'Manifesto against usury and the servitude of money interest', written by Feder in 1918, possibly based on Knapp, is included in its central axes of an economic nature in the program of the National Socialist Party. Surely a selection of some of Feder's paragraphs will make his position even clearer and the position adopted by Germany in 1933:

\begin{abstract}
"The interest loan thesis is the diabolical invention of big money. Only big money makes possible the indolent life of a drone for a minority of powerful money, at the expense of the creative people and their capacity for work; it is big money who has led to the abysmal, irreconcilable contrasts, to class hatred, from which the civil war and the fratricidal struggle are born." [Feder, (2012), p.19] 'Whoever wants to fight capitalism must break the servitude of interest' (p.20). "The Gospel of the loan at interest, outside of which there is no salvation, has trapped all our thinking in the golden nets of the international plutocracy" (p.23). "Sorry, then, dear people, in short it was for you, but let's not continue playing hide and seek, I, the State, no longer pay more interest and you, the taxpayer, do not need to pay taxes to pay these interests" (p.38). "Money is only and exclusively a bond issued by the State of a community on work done." (p.60)
\end{abstract}

The case of China, which has a currency issued by the government, along with a system of national banks owned by the state. The People's Bank of China, created by law in 1995, directs money to where the country needs it most [Hodgson, (2015), pp.259-261]. China's 'economic mystery' can be explained by the Keynesian observation that when workers and raw materials are available to increase productivity, adding money ('demand') does not increase prices, it increases goods and services. The supply keeps up with the demand without affecting prices' [Hodgson, (2015), p.265]. Hodgson is referring to the 'neutrality of money', and although Keynes does not make a specific development on the subject, since: "The depression of the 1930s shifted attention away from the subtle problems of monetary neutrality and toward the potential of monetary policy for short run stimulus. Keynes's general theory (1936) was one product of this change of focus" [Lucas (1995), p.253].

Chinese nationalism, whose ideological bases are found in Sun Yat-sen (1866-1925), as a remedy to prevent the disintegration of China and a unifying instrument of the different ethnic groups, in the face of foreign imperialist invasions [Chen, (2014), p.31]. Based on the social harmony theorised by Confucius called 'World equality', Sun Yat-sen embodies the so-called 'Three principles of the people': 
1 The nation (unification of races).

2 Civil law (right of election, right of dismissal, right of citizen initiative and right of referendum), where they lie: the power of the people, the governance of the people and the benefit of the people.

3 Well-being (agrarian reform and control of capital), the ideological base in order to save the country, increase political and economic competitiveness, and perpetuate the Chinese nation 'forever'.

The agrarian reform consisted of the expropriation of land from the large landowners and distributing them among the people for their usufruct. In relation to the control of capital, it was based on the development of three national industries: the communications network, mining and heavy industry (pp.32-35).

These three 'People's principles' are the reflection of the future China, equality of land rights and the solution to capital restrictions (p.36).

In China, 'it is the Taiping Rebellion ${ }^{12}$ that constitutes the introduction to the events of the 20th century' [Kiernan, (1952), p.319], which took shape with the Chinese Revolution of 1949, with elements of the 'Principles of the People' and 'Maoism' as 'an adaptation of Marxism to the particularities of China' [Kiernan, (1952), p.337].

In the case of Iran, after the 1979 revolution, the central bank, renamed Central Bank of the Islamic Republic of Iran, established through the 'monetary and banking law of Iran', the prohibition of earning and paying interest. In 2007, although it returns to an interest-free system, the designated director of the institution establishes that income will be obtained by charging commissions for services, instead of charging interest on loans [Hodgson, (2015), p.403].

The issue of financial interests in 'Islam' has religious roots; including several verses from the 'Koran' include the condemnation for charging interest. For Muslims, any collection of bank interest is usury $\left(\mathrm{riba}^{13}\right)$, and is the foundation of the Islamic Banking System [Hernández, (2014), pp.63-68].

In all these applied models of national currency, there is a constitutive and essential element in the implementation of these models, such as nationalism, which incorporates the rejection of foreign domination and the industrial development of the country. In the case of Iran, in addition to nationalism, there is the religious component, which in turn feeds off nationalism.

With all these elements, both theoretical and practical, it can be said that: the essential characteristics of a new form of money at the national level, are largely contained in the neutrality of money:

- Eliminate the oligopolistic position of financial institutions and all types of monopolies and oligopolies in any sector of the economy, as they represent distorting elements of this at the national level (neutrality of money).

- Create a 'national credit body' that will be the only one authorised to create money at the national level and that channels credit for all types of projects of national interest (neutrality of money).

- Facilitate access to credit for families and small and medium-sized enterprises (money neutrality). 
- The type or interest rate must be determined based on that it covers the operational costs of the national credit body and in turn finances the costs of the State. In this way, the State will require lower taxes to cover the cost of its proper functioning (neutrality of money and based on real applications).

- Generate a facility for access to credit, for import substitution projects, fossil energy substitution projects, educational, cultural and social projects, research projects, health projects, etc. (money neutral and based on real applications).

- In general, a national credit body aimed at correcting inconsistencies in the internal monetary system, and with a clear orientation of not allowing the concentration of wealth, or the generation of oligopolies and monopolies. That is to say, with a body with responsibilities for the universalisation of the credit system, with social responsibilities regarding credit orientation, responsible for the internal monetary mass and corrector of market imperfections (neutrality of money).

- Finally, this body must have a superior body, supervisor and auditor of its operations at the national level.

\subsection{Proposal of international money}

The common denominator of the different ideological trends that have influenced the economy, coincide in that gold has been a relatively useful tool for international exchange. Gold has been and continues to be a good reserve asset, it is no coincidence that many countries in recent years have been increasing their gold reserves and thus replacing their reserves in dollars, as is the case of Russia, China, India, etc. But despite being a good reserve asset, it is not the best alternative as an international exchange currency, for the same reasons that internally it was replaced by paper or certificates, the difficulty of moving it from one place to another, hinders operation and it has also been subject to manipulation in the markets through future contracts.

Before the IMF was established, Keynes in 1943 had carried out an important plan in the famous 'Proposals for an international clearing union', also known as the Keynes Plan. This document raises the need for an instrument of international currency of general acceptance, which it calls 'bancor', as a reference for international transactions, which each country may carry out with its own national currency. This mechanism would avoid fluctuations in gold reserves or in the reserve currency, as a result of speculative movements, discovery of new deposits, arbitrary changes, etc. This approach is part of the clear conviction that the gold standard system did not work properly and was the cause of the economic crises that had occurred [IMF (1969), pp.19-21].

The objections to Keynes's proposals were mainly aspects of national sovereignty and flexible exchange rates. Since the Keynes Plan required the creation of a superbank to manage the bank, this forced all countries to renounce their reserves and accept the fiduciary issuance of a super-authority institution without a super-state. This in turn meant that borrowers would not be forced to accept the institution's suggestions and investments, being able to renounce both, if they deemed it appropriate. Also this institution would not be a world central bank, since its obligations in reserves would only circulate among the national central banks and they would maintain complete control over their emissions within their country. Regarding stable rates, subject only to readjustments in cases of impossibility of preserving cost competition, for the long-term 
balance of the balance of payments at optimal levels of employment, growth and trade liberalisation, which requires all countries to assign in the direction of an international equalisation account. On the other hand, a flexible exchange rate would hardly fail to introduce a permanent predisposition towards devaluation and speculation [Triffin (1968), pp.85-88]. Before it had been the pound sterling, with similar catastrophic characteristics to the current dollar, which despite its malfunction, was backed by gold.

Triffin's (1968, p.97) approach, in relation to the opposite extreme of the gold standard, is "to conceive a 'universal standard of national currencies', in which all the imbalances in the balance of payments would be settled through the unlimited acceptance by the countries with surplus, of the currencies of the deficit countries as international reserves", thus ensuring unlimited financing through automatic loans that the countries with surplus would assume. Although Triffin $(1968$, p.97) was quite skeptical, given the implications of the system, because the creditors would not want to assume the automatic loans and, on the other hand, the lenders would not have participation on the power of international monetary creation.

It is very likely that international exchanges will begin to undergo quite profound changes, increasing exchanges in the currencies of the countries that sell their products, especially in Asia and which will later affect other regions, mainly due to distrust in the dollar. Also, some countries will develop their own digital currencies, based on blockchain technology, which will facilitate international exchange. China, which is already in a trial period internally with its digital currency, will surely be the first to initiate international transactions in virtual currency; but Europe is also in the same line of work, with the digital euro.

However, the time will come when countries will have to come together to develop an international exchange currency, which will depend on the fall of the dollar as reserve currency, as a result of its devaluation in international markets, due to excess monetary issuance and as a result of the use of international exchange systems, which depend on the US (SWIFT System), as a tool to pressure certain countries, causing the loss of confidence in the currency, a situation that is already occurring and that it will surely be aggravated by the coronavirus pandemic.

The substitution of an international currency, although it obviously requires international agreements from all countries, will only be the countries with the greatest weight at the world level that will be able to produce the changes and, unfortunately, perhaps without taking into account the poorest countries. However, despite this decision being made in the north of the world, the basic characteristics of this international exchange currency should have at least the following aspects:

- Decisions on a new international exchange currency, presupposes a profound transformation or the elimination of international credit organisations, such as the IMF, World Bank and others of similar characteristics (neutrality of money).

- The international currency cannot be defined on a currency for internal use of any country due to the effects that its internal monetary decisions may cause at the international level (Triffin's dilemma). Therefore, it cannot be made up of a basket of currencies from different countries, such as the SDR, since the monetary effects of internal decisions would decrease, but they would not disappear (neutrality of money). 
- Any international currency that is established cannot be subject to manipulation or speculation of the markets (neutrality of money).

- An international currency must be subject, in one way or another, to a problem of international confidence, to a merchandise and better still to a set of merchandise that is traded internationally, but that cannot be the object of the foregoing, that is to say, goods that can be free from their manipulation in prices (neutrality of money). An international currency similar to that proposed by Greco (2001) for a local currency, a credit compensation exchange system (LETS).

- If an international currency is established through the merchandise basket, these merchandise it contains must be traded regularly and freely at the international level (neutrality of money).

- This currency, similar to the one proposed by Keynes (Bancor) but backed by merchandise and therefore, its fluctuation is not subject to variations between different currencies, but its variation will be subject to a set of merchandise that will fluctuate freely. in the market and in whose price labour is incorporated (neutrality of money).

- $\quad$ This, as Keynes himself said, will force the creation of a kind of World Central Bank, but totally independent of any State.

- In this way, the states will be able to offset their transactions in this currency to pay for their imports, with their own exports.

- The deficit or surplus of the trade balances of the countries will generate credits or loans to them, which must be regulated by this new supranational institution, the 'World Central Bank' (Keynes). This will tend, in one way or another, to balance the trade balances of the countries and promote mutual aid for the development of countries with less export capacity (increased international cooperation), with those countries with great export power.

\section{Conclusions}

The historical conformation of the international monetary system, with impacts on the national monetary systems, was built through technical discourses with content of an ethical capitalism which generated disciplinary and control mechanisms and was ultimately built on a capitalist governmentality, transformed in the last 50 years, in a corporate governmentality.

In this construction, market imperfections have predominated; imperfections that have been the product of the development of ideological economic theory itself and imposed as the dominant discourse, as well as the product of the imposition of the private financial banking sector, not only in the present, but also from its origin.

In this work, which uses a genealogical archaeological methodology or historical review, with the elements of that particular historical moment, together with the existing power relations in each stage of those historical moments, the manipulation of economic language is revealed, like the powers in the background that press for the construction of this discourse. Using the metaphor used by various economists, such as Gregory Mankiw, 
Paul Krugman or Ellen Hodgson, about 'The Wizard of $\mathrm{Oz}$ ' ${ }^{14}$, it is revealed behind the curtain who really is pulling the strings of the 'Wizard of Oz' and although this story does refer to late 19th century bimetallicism, its metaphor could be applied to debt money. The permanent crises and now the health crisis have exposed the imperfections of the system.

Behind the curtain that has been exposed, how a small oligopolistic group at the level of each country have taken control of the money supply exclusively, and the same happens with the main international exchange currency, using this great tool to benefit their own interests and not, as it should be, for the benefit of the economy as a whole. The exchange value has been held captive, facilitating the concentration of wealth, generating inequality and precariousness.

In this paper, the process of manipulation of economic theory is described with special emphasis on the 'neutrality of money' and develops a proposal for the national currency and for the international exchange currency. These proposals are made based on economic theory and practical cases, in the case of the national currency and in the case of the international currency, the proposal is made through the correction of inconsistencies and anomalies in the monetary system, together with proposals carried out previously by Keynes and Triffin and having the 'neutrality of money' as its central axis.

The proposal for an international exchange currency corrects what has been called the 'Triffin dilemma' or the parallel use of an internal exchange currency, as an international exchange currency, since internal monetary measures will negatively affect other countries. It also eliminates the monopoly of exchange channels established by the dominant economy, it eliminates the financing of deficits in the economy's trade balance with the dominant currency and makes international exchange transparent and eliminating any speculative monetary effect.

The national currency proposal proposes the elimination of the inefficient manager or managers of the money supply, within a country, to be replaced by a manager that acts according to the interests of the economy as a whole. It is a task that can only be carried by out the state. In this way, the efficiency of the allocation of monetary resources (money supply) will achieve:

1 That the increase in the money supply is in line with the productive and service needs that the country requires, correlating the growth of the money supply with production growth and therefore employment growth (money neutrality).

2 Eliminate excesses of unproductive money supply, destined for speculation and overvaluation of assets, which end in economic crisis.

3 Eliminate the financial game of the economy as a whole, such as, derivatives for speculation and that feed back the money supply, eliminates the buyback of own shares, which increase the share value in a speculative way and eliminates the possibility of diverting profits to tax havens.

4 The efficient allocation of the money supply has a direct impact on the other resources of the economy being allocated efficiently (facilitating the elimination of imperfect agents, such as monopolies, oligopolies, monopsonies or oligopsonies).

5 The increase of control over the monetary resources of the economy as a whole. 
6 The end of the financing of the State with interests that transfers to private third parties, with the possibility of channeling these resources to lower taxes for families or in higher social welfare policies.

7 Finally, sustainable production, understood as production that is responsible for life.

The replacement of the money supply manager not only corrects imperfections in the monetary system but also corrects multiple economic imperfections, which naturally generates an inefficient money manager. An efficient manager of the domestic money supply will also influence the trend of the natural balance of the trade balance. This is fundamentally due to the policy of low indebtedness which will also influence a low external indebtedness, aimed only at covering the deficit of the trade balance, and this indebtedness can only be paid through an increase in exports, to have access to the international currency, causing the trend towards a policy of import substitution and therefore, a trade balance with a tendency to equilibrium. This necessary balance in the trade balance, in turn, will cause an increase in international cooperation industrialising less developed countries through joint projects between countries.

\section{References}

Alonso, M., Bagus, P. and Rallo, J. (2011) 'Teorías del ciclo económico: Principales contribuciones y análisis a la luz de las aportaciones de la Escuela Austriaca de Economía', Tendencias y Nuevos Desarrollos de la Teoría Económica, No. 858, pp.71-87.

Castro, E. (2011) Diccionario Foucault, Siglo XXI Editores, Buenos Aires.

Chen, C-I. (2014) Tesis Doctoral: Radicalización del nacionalismo chino moderno: orígenes y desarrollo del facismo chino, Departament d'Historia Moderna i Contemporània, Universitat Autònoma de Barcelona, Barcelona, Spain.

Emry, P.S. (1984) Billions for the Bankers and Debts for the People, America's Promise Ministries, USA.

Expansión (2020) Estados Unidos - Balanza Comercial [online] https://datosmacro.expansion. com/comercio/balanza/usa (accessed 15 May 2020).

Feder, G. (2012) Manifiesto contra la usura y la servidumbre del interés del dinero y otros escritos, Ediciones Wandervögel, Buenos Aires, Argentina.

Foucault, M. (1994) Dits et ecrits 1980-1988, Vol. 4, El Sujeto y El Poder, Paris, Gallimard.

Foucault, M. (2011) Seguridad, Territorio y Población: Curso en el Collège de France: 1977-1978, Fondo de Cultura Económica, Buenos Aires.

Foucault, M. (2012) Nacimiento de la Biopolítica, Fondo de Cultura Económica de Argentina S.A. Argentina.

Friedman, M. and Schwartz, A.J. (1963) A Monetary History of the United States, 1867-1960, Princeton University Press, for the National Bureau of Economic Research, Princeton.

Gowan, P. (2010) Crisis financiera económica sistémica, Capitulo 4, Las causas de la crisis del crédito, Maia Ediciones, Madrid.

Greco Jr., T.H. (2001) Money Understanding and Creating Alternatives to Legal Tender, Chelsea Green Publishing Company, USA.

Harvey, D. (2007) Breve historia del neoliberalismo, Ediciones Akal, S. A. España.

Hayek, F.A. (2010) Ensayos de Teroría Monetaria I, Unión Editorial, Madrid, España.

Hernández, A. (2014) Tesis Doctoral: La usura (Riba) en el occidente islámico medieval a través de las fuentes jurídicas, Facultad de Filología, Universidad Complutense de Madrid.

Hodgson, E. (2015) Telaraña de Deuda, Editorial Almuzara, España. 
Hume, D. (2008) Ensayos económicos. Los orígenes del capitalismo moderno, Editorial Biblioteca Nueva, Madrid, España.

International Monetary Fund (IMF) (1969) The International Monetary Fund 1945-1965, in Horsefield, J.K. (Ed.), Volume III Documents, pp.3-36.

International Monetary Fund (IMF) (2020) Special Drawing Rights (SDR) Valuation [online] https://www.imf.org/external/np/fin/data/rms_sdrv.aspx (accessed 15 May 2020).

Kiernan, V.G. (1952) Los orígenes de la revolución China, June, Separata de Revista Internacional de Sociología, Madrid.

Knapp, G.F. (1924) The State Theory of Money, Macmillan and Company Limited, London.

Lazzarato, M. (2013) La fábrica del hombre endeudado, Amorrortu Editores, S.A. Buenos Aires, Argentina.

Lucas Jr., R.E. (1972) 'Econometric testing of the natural rate hypothesis', in Otto, E. (Ed.): The Econometrics of Price Determination Conference, Board of Governors of the Federal Reserve System, Washington.

Lucas Jr., R.E. (1973) 'Some international evidence on output-inflation trade-offs', American Economic Review, Vol. 63, No. 3, pp.326-334.

Lucas Jr., R.E. (1995) 'Monetary neutrality', Prize Lecture, December 7, pp.246-265, University of Chicago, USA.

Marx, K. (1976) Grundrisse. Elementos fundamentales para la crítica de la economía política. Borrador 1857-1858', Siglo XXI Editores, Madrid, España.

Marx, K. and Engels, F. (2017) 'El Capital. Crítica de la economía política. Libro Tercero. El proceso global de la producción capitalista, Siglo XXI de España Editores, Madrid, España.

McCandless Jr., G.T. and Weber, W.E. (1995) 'Some monetary facts', Federal Reserve Bank of Minneapolis Quarterly Review, Vol. 19, No. 3, pp.2-11.

McLeay, M., Radia, A. and Thomas, R. (2014) Money Creation in the Modern Economy, Bank's Monetary Analysis Directorate, Quarterly Bulletin 2014 Q1.

Phillips, A.W. (1958) 'The relation between unemployment and the rate of change of money wage rates in the United Kingdom, 1861-1957', Economica, Vol. 25, No. 100, pp.283-299.

Rivera Vicencio, E. (2012) 'Foucault: his influence over accounting and management research. Building of a map of Foucault's approach', International Journal of Critical Accounting, Vol. 4, Nos. 5/6, pp.728-756.

Rivera Vicencio, E. (2014) 'The firm and corporative governmentality. From the perspective of Foucault', Int. J. Economics and Accounting, Vol. 5, No. 4, pp.281-305.

Rivera Vicencio, E. (2016a) 'Monetary conformation of the corporate governmentality I. From the new art of governing to the beginning of neoliberal governmentality', Eurasian Journal of Economics and Finance, Vol. 4, No. 2, pp.72-90.

Rivera Vicencio, E. (2016b) 'Monetary conformation of the corporate governmentality III. description of the monetary system', Eurasian Journal of Economics and Finance, Vol. 4, No. 2, pp.18-41.

Rivera Vicencio, E. (2018) 'Conformation of the primitive accumulation and capitalist spirit. Theory of corporate governmentality', Int. J. Critical Accounting, Vol. 10, No. 5, pp.394-425.

Rivera Vicencio, E. (2019) 'Inequality, precariousness and social costs of capitalism. In the era of corporate governmentality', Int. J. Critical Accounting, Vol. 11, No. 1, pp.40-70.

Robertson, J. and Bunzl, J. (2003) Monetary Reform - Making It Happen, International Simultaneous Policy Organisation, London, U.K.

Samuelson, P.A. (1958) 'An exact consumption-loan model of interest with or without the contrivance of money', Journal of Political Economy, Vol. 66, No. 6, pp.467-482.

Sargent, T.J. (1986) 'The ends of four big inflations', in Rational Expectations and Inflation, Chapter 3, Harper and Row, New York.

Smith, A. (2017) La riqueza de las naciones, Alianza Editorial, S.A. Madrid, España. 
Stockman, A.C. (1996) Introduction to Economics, The Dryden Press, Fort Worth.

Streeck, W. (2017) ¿Cómo terminará el capitalismo? Ensayos sobre un sistema en decadencia, Traficantes de sueños, Madrid.

Triffin, R. (1968) El sistema monetario internacional, Amorrortu Editores, Buenos Aires, Argentina.

Vergés, J. (2019) Economía del mundo real, Ediciones Pirámide (Grupo Anaya, S.A.), Madrid, España.

Zarlenga, S.A. (2002) The Lost Science of Money, American Monetary Institute, USA.

\section{Notes}

1 The Firm and Corporative Governmentality. From the perspective of Foucault (Rivera Vicencio, 2014).

2 Security, Territory and Population (Foucault, 2011).

3 The Birth of Biopolitics (Foucault, 2012).

4 https://www.imf.org/external/np/fin/data/rms_sdrv.aspx. Daily price according to the weighting of currencies and the exchange rate against the dollar of the SDR or SDR in English (Special Drawing Rights).

5 Data extracted from Expansión (2020) https://datosmacro.expansion.com/comercio/balanza/ usa (accessed 16 May 2020).

6 The International Monetary System (Triffin, 1968).

7 'Consolidating state' as an absolute loss of sovereignty. An equivalent to 'corporate governmentality' by Rivera Vicencio $(2014,2019)$.

8 'The increase in commodities makes them cheaper, while the increase in money increases their value' [Hume, (2008), p.101].

9 M-C-M is the relationship money-commodity-money.

10 The model no longer requires savers, except to launder excessively issued money, which is done through pension funds, transferring overvalued assets to these funds and encouraging savers to invest in financial documents and derivatives, also overvalued.

11 The minimum vital income, in addition to generating greater indebtedness to the country and therefore higher interest payments, together with the capture of the State by the financial system, also represents a transfer to the private sector, not only to cover its basic needs of people but also to detach the State from social responsibilities, such as health, education, welfare etc. The minimum vital income must be treated as a complement to the social rights that the State must provide and through national money, which does not mean indebtedness.

12 Mid 19th century.

13 Translation of usury or abusive profits.

14 Oz: abbreviation for ounce of gold. 